\title{
Effectiveness of an instructional design in the academic performance of students of an online course
}

\author{
Volumen XIX No (1). Enero-Junio 2019. Pág. 79-90 \\ ISSN: 0121-1048 IMPRESO ISSN: 2422-3220 EN LÍNEA
}

\author{
Quiroz Campas, Celia \\ Yaneth: \\ Instituto Tecnológico de Sonora, \\ Ramón Corona S/N Col. ITSON, \\ CP.85860. Navojoa, Sonora, \\ México 85860. \\ celia.quiroz@itson.edu.mx \\ Autor correspondiente
}

\author{
Armenta Zazueta, Lizeth. \\ Instituto Tecnológico de Sonora, \\ Ramón Corona S/N Col ITSON, \\ CP.85860. Navojoa, Sonora, \\ México. \\ Lizeth.armenta@itson.edu.mx
}

\author{
Hinojosa Rodríguez, \\ Carlos Jesús \\ Instituto Tecnológico de Sonora, \\ Ramón Corona S/N Col ITSON, \\ CP.85860. Navojoa, Sonora, \\ México. \\ carlos.hinojosa@itson.edu.mx
}

\begin{abstract}
The purpose of this research was to elaborate an online instructional design, and to identify the effectiveness of the academic performance on a course of the educational program bachelor's in administration of a University of northern

Mexico. The course was taught in "SAETI, Sistema de apoyo a la educación con tecnologías de internet" (Support System to education with Information Technologies). The instructional design of the course was tested on this platform with students of fourth and fifth semester. This research was done under a quasi-experimental focus with a quantitative approach. Once the online instructional design was developed, an evaluation instrument was applied to measure the effectiveness of the use and application of an online instructional design. The student sample to be selected was made with two natural class groups, one control and one experimental group. In addition, three research questions were answered, the first question refers to the differences in the academic performance of students in an online course, when an instructional design is used. According to the results it is verified that there are significant differences in the experimental group, where an online instructional design was used, and it is demonstrated with the result of the $t$ student test. For the second research question, the advantages for the student are presented, the effectiveness of the application of an instructional design in the activities of an online course and the third research question investigated what the advantages for the teacher in the use of an instructional design in an online course are; the findings of this research showed that the instructional design used in the two units of competence was effective:
\end{abstract}

Keywords: instructional design, academic performance, instructional design models, learning theories

Code JEL: I20, I21, I23

\footnotetext{
• Citar: Quiroz Campas, Celia Yaneth, Armenta Zazueta, Lizeth and Hinojosa Rodríguez, Carlos Jesúsr (2019). Effectiveness of an Instructional Design in the Academic Performance of Students of an Online Course. Inquietud Empresarial, XIX (1), 79-90.
} 


\title{
Efectividad de un diseño instruccional en el rendimiento académico de los estudiantes de un curso en línea
}

\begin{abstract}
Resumen
El propósito de esta investigación fue elaborar un diseño instruccional en línea, e identificar la efectividad del rendimiento académico de un curso del programa educativo de licenciado en administración de una Universidad del Norte de México. El curso se impartió en el Sistema de Apoyo a la Educación con Tecnología de Internet, denominado Saeti. En él se probó el diseño instruccional del curso, con alumnos de cuarto y quinto semestre. Esta investigación se realizó de tipo cuasi-experimental con un enfoque cuantitativo. Una vez elaborado el diseño instruccional en línea, se aplicó un instrumento de evaluación denominado cuestionario para medir la efectividad del uso y aplicación del diseño instruccional en línea. Derivado de lo anterior, la muestra estudiantil a seleccionar se realizó con dos grupos naturales de clase, el primer grupo fue de control y para el segundo grupo fue experimental. Además, se dío respuesta a tres preguntas de investigación, la primera pregunta se refiere a cuáles son las diferencias en el rendimiento académico de los estudiantes de un curso en línea, cuando se usa un diseño instruccional. De acuerdo a los resultados se comprueba que sí existen diferencias significativas en el grupo experimental, donde se utilizó un diseño instruccional en línea y queda demostrado con el resultado de la prueba t-student. Para la segunda pregunta de investigación, se presentan las ventajas que tiene para el estudiante, la efectividad de la aplicación de un diseño instruccional en las actividades de un curso en línea y la tercera pregunta de investigación indagó cuáles son las ventajas que presenta para el profesor, el uso de un diseño instruccional en un curso en línea; los hallazgos de esta investigación mostraron que el diseño instruccional utilizado en las dos unidades de competencia fue efectivo.
\end{abstract}

Palabras clave: diseño instruccional, rendimiento académico, modelos de diseño instruccional y teorías de aprendizaje.

Códigos JEL: I20, I21, I23

\section{INTRODUCTION}

Due to the raise in Information and Communication Technology, it's necessary to modify the traditional schemes in design and planning of learning courses and materials and use technological tools through reflexive and adaptative optics for the new learning models (Góngora y Martínez, 2012).

The purpose of this study is to elaborate an online instructional design and measure its effectiveness for a Degree in Administration course program in a university in the north of Mexico. Amaro de Chacín (2011) says that the components in the models and systematic strategies of instructional design in virtual teaching and learning settings are similar and can be applied through a reflection of strengths and weaknesses.

According to Martínez (2009) in the educational area, regardless the modality, an instruction is designed with the finality of enhance the development of skills and stimulate the knowledge acquisition directly. It's evident that there is a necessity of following a plan or methodology when the aim is to develop not just one but several instructions inside a course or a class organization.

The bachelor's degree in Administration is offered in a face-to-face modality at a university in northern Mexico, but it crosses 
a confusion when offering this subject in the virtual-classroom modality, since professors teach the course via e-mail. Given this, in an interview with the professional practice coordinator in the program, it was done with the purpose of knowing the current situation in this modality, the coordinator refers that in this moment, there isn't a course developed in an instructional design, and that it would be very important to start working in this topic to improve performance in the teaching-learning process (BA Program Coordinator, personal communication, August 25th, 2018).

On the other hand, it is stated that an online instructional model hasn't been created or standardized (Division Dean, personal communication, August 25th, 2018) causing a disarticulation in the process of teaching each subject of the program. This online course proposal was generated from the need to support a group of graduates to finish their bachelor in a certification process.

As said by Rodríguez y Arbey (2012) the instructional design in some educative institutions is more considered as the result of empiric labor than fundament in well-known theories, models and systems in the academic field. Proof of that are many institutions that even though they have specific guidelines for the creation of new produced courses, they lack documents that support both epistemological and structurally.

Rodríguez y Arbey (2012) affirm that is pertinent to begin alluding the common belief in the academic community: to think that the role of the instructional designer is limited, either to the structuring of the contents of a course or to the correction of the style of the educational material and, in other cases, to the graphic and multimedia design. The problem relays on the fact that the platform is given but there's a lack of online instructional designs for the course, so it is necessary to formalize immediately. All of this in order for students, teachers and program coordinators have standardized knowledge equally from their homes or if the student works, there will not be limitation for the lack of time to take a class in a face-toface modality.

According to Rodriguez and Arbey (2012), it is a fact that the instructional design is a growing field, but at the same time there is no clue that implement this will require more of the professionals and that it won't be easy to build materials for the so called digital wise (Prensky, 2009), with their skills to find information, the natural style to go through technological environments and the possibility to improve their intelligence with the help of technology.

According to the literature review and the problem statement, the research questions for this study are:

$\Rightarrow \quad$ What are the differences in the student's academic performance of an online course when an instructional design is used?

$\Rightarrow \quad$ What are the advantages perceived for the student, and the effectivity of the instructional design in the activities of an online course?

$\Rightarrow \quad$ What are the advantages perceived for the professor, to the use of the instructional design in the activities of an online course? 


\section{LITERATURE REVIEW}

This review shows a detailed analysis of the basic theories and related work of this study. According to the review, the instructional design is considered a pillar of educational technology. There are hundreds of models about instructional design and development; nevertheless, in use there is a much smaller number. Martinez (2009) notes that under cited experiences, it's purposed that the instructional design works should be done by an interdisciplinary expert team, that can contemplate the possibility of doing this in a holistic way, in order to find the best of each theory and model to improve the work to develop.

Amaro de Chacín (2011) confirm that didactic constitutes, from a critic and constructive perspective, a theoretical framework of reference for the actions that the professor, facilitator and moderator in online settings (as face-to-face) should do before, during and after the didactical or instructional process, actions that conveniently based and designed are identifies upon the phase of such process as: pre-active, inter-active and post-active. The pre-active phase refers to the didactic planning process, necessarily linked with the curriculum planning, where must contemplate the curriculum specification stablished and from there design the educational action depending on the subject's learning. In the inter-active phase, the didactical process is managed and facilitated previously planned, in which the interaction between professor-student and between students is developed and in the post-active phase the evaluation and quality control is concreted, therefore, it stimulates the reflection and feedback during the entire didactic process.

The instructional design models bring guidelines or structures to help organize procedures to design and develop educational activities (Sharif and Cho, 2015). From a designer's perspective, several models can be applied in the instructional design process. In May 2011, Sharif and Cho made a poll in an event called Instructional Design, celebrated in Vancouver, British Columbia, Canada. There were 60 participants and it was addressed to professionals in public schools or private companies where worked as designers or were involved in the instructional design process. Results showed a general description of the roll of the designer in an instructional model and the challenges presented, nowadays it's not a very common topic inside the academic institutions due to the lack of divulgation and research about it. Thus, this study shows that people who carry out this work strive to catch up with technology, since young people live around it and there's a need to compete with these new updates to be interesting, not just for the students and professors but for the academic managers to keep supporting these activities.

Valdes, Mendez and Rivas (2015) affirm that the instructional design model selection depends upon the characteristics in addition to the educative theories and principles in which they are based on (p. 67). Therefore, each model must be deeply analyzed, based on the tools, evidences supporting the development, validity of the knowledge acquired by the student and the follow up of the design to measure outcomes before and after the implementation. It's important to note that designers must be trained to contribute to their classes in an appropriate way according to their profession and 
improve outcomes of the student's knowledge under this context. Sharif and Cho (2015) introduce a new conceptual framework in this topic called "the civicminded instructional design framework by adapting Kaufman's organizational elements model to explain three levels of organizational planning: micro, macro and mega" (p. 81). Organizations must add value to their clients, thus, in an academic institution the main clients are the students work every day people work to offer an educational alternative within their reach. According to Clerici, Fernandez and Monteverde (2015), academic performance is the result obtained by the student in a professor's evaluation in agreement to the class path in a determined time lapse, considering the test results, practices and assignments.

Over the years, it has been a huge challenge to define with a determined structure the student's performance, since every student has different skills and capabilities that help the professional and personal development, for that reason it should be analyzed not only the quantitative but the qualitative aspects of the students to determine a result with clear evidence of before and after the class end. However, if this is related to an online class evaluation it will turn into a platform to leave evidence of the student enrolled in a registered subject but not in a face-to-face modality. Hence, it's important to prepare the students to not impact the academic performance and train them in such a way that it is not an obstacle to the desired result of the learning.

\section{Methodology}

This chapter aims to describe the methodology used in this study, where the main objective was to elaborate an online instructional design to measure the effectiveness an academic performance in a subject of the bachelor's in administration a University of Northern Mexico. The structure of the chapter is organized in the next subthemes: (a) participants, (b) instruments, (c) procedure, (d) data analysis and (e) limitations.

\subsection{Participants}

The population of the study was formed by bachelor's in administration students of the university where the study was developed. The ages range from 20 to 24 , man and woman taking fifth and sixth semester courses. Derived from the above, the student's sample was arranged with two natural class groups, the control group was the group were the teacher taught class in a traditional way. For the second group, the online instructional design was elaborated and applied in a platform of the same university called "SAETI, Sistema de apoyo a la educación con tecnologías de internet" (Support System to education with Information Technologies). The inclusion criteria were teachers and students ascribed to the Bachelor's in Administration, in the semester from August to December, also, two teachers of the specific subject participated in the study to answer a questionnaire about the third research question, related to the advantages for the professor in traditional or virtual modality, of an instructional design of an online course. The present study was observational, descriptive and correlational since the measurement was through a poll, the application was developed to the previously formed groups, randomly assigned but formed by the coordinator of the school program, following the regular procedure. 
Effectiveness of an instructional design in the academic performance of students of an online

course

\subsection{Instruments}

For the data collection, a final evaluation instrument was used called Questionnaire to measure effectiveness of the use and application of an online instructional design. The questionnaire was developed by Camacho (2012). It measures the advantages for the students and professors in the activities of an online course with the application of an instructional design.

The instrument consists in three parts, the first part describes generally the purpose of the instrument and the way to answer the statements presented, where it's explained that the answers are anonymous for more objectivity. The second part consists of 15 questions answer by the students. This part answers the research question about the advantages for the students of the effectiveness of the application of an instructional design for the activities of an online course. The last part contains 6 questions for the subject's teacher, with the purpose of collecting information and answer the third research question, related to the advantages for the professor of the use of an instructional design in the activities of an online course.

Regarding the reliability of the instrument, Camacho (2012) ran an internal consistency method based on Cronbach's Alpha, which allowed estimating the reliability of the instrument through a set of items. This was done with a pilot test with 10 participants, students and teachers randomly selected in a university. The result showed a Chronbach's Alpha of 0.87 which it's considered a reliable instrument; $t$ was also validated with three experts and focus groups in meetings to review each of the questions and answers in the educational field for better support for the instrument, in order to adjust and improve for a more efficient application.

\subsection{Procedure}

Design. This study was developed with an observational, descriptive and correlational methodology since it was measured through a poll. According to Hernandez, Fernandez and Baptista (2010) in this type of design, the participants are not assigned randomly, since the groups are already formed before starting the study in the university.

Data Analysis. To answer the first research question, about the academic performance in students, a Student's T-test was applied which allows to appreciate if two groups shows significative difference between them related to arithmetical means in a variable (Hernández, Fernández y Baptista, 2010, p. 319). To achieve the above, first the means and the standard deviation of each group were obtained. Once the results were obtained, the student's t-test was applied and the degrees of freedom were calculated, the $t$ value was identified as significant. The greater number of degrees of freedom presented, the distribution $t$ will be closer to be a normal distribution (Hernández et al., 2010).

As to the second research question, it refers to the advantages for the student in the application of an instructional design in the activities of an online course. For this purpose, descriptive statistics were used with means charts where a means comparison was made to order and summarize the data obtained in the research, concentrating it in charts where a matrix was applied with the obtained results. The matrix was made with Statistical Package for the Social Sciences (SPSS) 16th version for Windows, in the 
option of data analysis and thus be able to analyze the values that correspond to each question focusing the results thrown by the program for the control and the experimental group.

Limitations. Within this study the limitations that could affect the validity and reliability of the results of the study, are that few students are enrolled in the semester corresponding to the research. Considering that the selection of students of the educational program of the University study, since according to Hernández et al (2006) in a causi-experimental study the subjects will not be randomly assigned to the groups. for this case the groups were integrated by the university under study before the experiment, and no method will be used for student selection. This may affect the results, since students and teachers with prior knowledge of the research will not be prepared. Another limitation with the course of the subject to be taught is rigid and not flexible; they are already prepared, but to be taught in person and no changes can be made, considering that all the materials of the instructional design will be developed online based on an already established course program.

\section{RESULTS}

For the first research questions, data were collected with the grades obtained within the time stipulated of two competence units of the course by the educational program of bachelor's in administration, the lowest grade is showed with 7 and the highest with 10 . According to the results in the experimental group, the lowest grade was 9 and the highest was 10 . Also, in an inferential way and under a standard statistical method like the T-test implemented with the statistical package SPSS (16th version), it was observed, with a significance below $0.01(\mathrm{p}$-value $=0.000)$ and with a reliability above $95 \%$, that there's a highly significative difference between the two groups. Table 1.

TABLE 1. COMPARATIVE ANALYSIS WITH T-TEST FOR MEANS EQUATION

\begin{tabular}{llllll}
\hline & & Sig. & & \multicolumn{2}{c}{ 95\% Confidence Interval of the Difference } \\
\cline { 4 - 5 } $\mathrm{T}$ & $\mathrm{df}$ & $(2$-tailed $)$ & Mean's difference & Lower & Upper \\
7.691 & 15 & .000 & 6.688 & 4.83 & 8.54 \\
\hline
\end{tabular}

Source: own development

Table 1 shows the analysis of the Student's t-test where it could be observed a trust interval in the inferior limit of 4.83 and 8.54 in the upper limit, having as a result a difference of 3.71 .

To obtained results of the difference between control and experimental group as to their grades, a table was applied based on descriptive statistics where a difference of 1.55 between the group means is showed, with an average grade of 7.20 for the first group and an average grade of 8.75 for the second group, see table 2 .

The standard deviation of the grades increased from 0.957 to 2.781 with a variance of 0.917 to 7.73 , which indicates that the results are more dispersed among the students that in the experimental group, than in the control group, which means for this study that the ratings of the experimental group comprise a greater range of (10-8), whereas the control group scores are more similar, associated with a confidence interval 
of $95 \%$ for the mean of the control group and the experimental group (see Table 3).

As to the second research question, about the advantages for the student on the application of an instructional design to the activities of an online course. After concluding the first 2 competence units, the instrument was applied and as it can be showed a minimum value of 4.46 and a maximum of 4.8 prevailed in the mean of the answers of the students, that corresponds to the fact that most of the participants agree and completely agree with the description of the items that were applied when evaluating their course in SAETI platform, while the result of the median and mode remains in 5 .

TABLE 2. DIFFERENCE BETWEEN EXPERIMENTAL AND CONTROL GROUP AS TO GRADES.

\begin{tabular}{|c|c|c|c|}
\hline Group & & & Statistic \\
\hline \multirow{11}{*}{$\begin{array}{l}\text { Experimental } \\
\text { Group }\end{array}$} & Mean & & 8.75 \\
\hline & 95\% trust Interval for the mean & Lower limit & 7.23 \\
\hline & & Upper limit & 10.27 \\
\hline & Trimmed mean to $5 \%$ & & 8.72 \\
\hline & Median & & 8.50 \\
\hline & Variance & & 0.917 \\
\hline & Standard deviation & & 0.957 \\
\hline & Minimum & & 8 \\
\hline & Maximum & & 10 \\
\hline & Range & & 2 \\
\hline & Interquartile Range & & 2 \\
\hline \multirow[t]{11}{*}{ Control Group } & Mean & & 7.20 \\
\hline & $95 \%$ confidence Interval for the mean & Lower limit & 5.21 \\
\hline & & Upper limit & 9.19 \\
\hline & Trimmed mean to $5 \%$ & & 7.50 \\
\hline & Median & & 8.00 \\
\hline & Variance & & 7.733 \\
\hline & Standard deviation & & 2.781 \\
\hline & Minimum & & 0 \\
\hline & Maximum & & 9 \\
\hline & Range & & 9 \\
\hline & Interquartile Range & & 2 \\
\hline
\end{tabular}

Source: prepared by the author

Likewise, the standard deviation was made based on the qualifications of the experimental group and control group of the study performed, was obtained to analyze the most common dispersion measure, which indicates how scattered are the data around the mean, where the minimum value of the items is 3 , which means that the students disagree with what the course describes.

As to the descriptive statistical analysis, it reflects a standard deviation that oscillates between a minimum of .45774 and a maximum of .74322 , which represents a difference in dispersion of only .28548.

TABLE 3. RESULTS OF DIFFERENCES IN GRADES

\begin{tabular}{ll}
\hline Group & Mean \\
\hline Experimental group & 8.75 \\
Control group & 7.20 \\
\hline
\end{tabular}

Source: prepared by the author

The above shows that students who answered the test agree and completely agree with the fact that there are advantages in the application of instructional designs to the activities of an online course, supported to the institutional platform SAETI, from the 
bachelor's in administration of a university in northern Mexico.

To answer the research question about the advantages for the professor to the use of an instructional design in the activities of an online course, a 6-item instrument was applied to the professor of the course. Results show that the professors completely agree that the platform SAETI facilitated in the design of the interactive activities of the course, to know deeply the skills and knowledge acquired by the students. On the other hand, the resources used, and the summative evaluation of the topics promoted by SAETI helped to get the academic performance of the students in time. Also, the professors agreed that the activities included in the platform allowed them to gain knowledge in an active learning process.

Derived from the above, the objective of the research is fulfilled, in which an online instructional design is elaborated and the effectiveness of the academic performance on the Bachelor's in administration course is identified.

\section{DisCUSSION}

The analysis and interpretation of the study was organized starting with the research questions statements. In the present study, it was used an online instructional design template for the SAETI platform. The course implemented for this study used the Course Design Template, which integrates elements such as: notifications, work tools, activities, support materials, individual work and Syllabus, where there was a general explanation for the student about each part of the platform, the participation in forums and specific requirements.
For that purpose, Work forums were developed, also, practices, exercises, questionnaires and learning models. Instructional materials, such as presentations, videos, example documents, were designed in the individual section of the platform for the student's use.

\subsection{Discussion for the first research question}

The differences between the student's academic performance in an online course, when using an instructional design, according to the results proves that there are significative differences on the experimental group where the online instructional design was applied; since the experimental sample shows the lowest grade as 9 and the control group shows 6 as the lowest. The control group showed lower grades than the experimental group.

Finally the t-test results of the group's grades shows that there's a significative difference on the student's academic performance when using an online instructional design course, it could be observed a significance lower than 0.01 (pvalue $=0.000)$ and a reliability of $95 \%$, therefore there are highly significative differences between the experimental and the control group since the difference between the two modalities is different than zero.

These results agree with the ones found by Dionne, Taasoobshirazi, Hendricks and Hickey (2012), who made a research taking as a reference 2 class groups, results showed that students linked to an activity in an online class using the Toulmin Model of Argument, in which online individual activities were applied to a virtual class to delivered the 
Effectiveness of an instructional design in the academic performance of students of an online

course

assignments, got better argumentative text structuration than the control group.

This kind of research supports the results obtained in the present study, since according to the mean comparison of the groups, showed in table 3 , the control group had an average grade of 7.20 while the experimental group had an average of 8.5 , there is a difference of 1.55 between the means of the groups.

Results obtained are similar to the study of Ortiz and Fernandez (2016) who found a better performance in terms of grades on an online Biotechnology course, since the collaborative work in virtual platforms supports the increase of final grades. The study made by these authors consisted of a comparison between two student's groups, but only on received orientations about virtual learning processes with an online instructional design.

\subsection{Discussion for the second research question}

To answer the objective related to the advantages for the student on the effectiveness of the application of an online instructional design course, the results were collected from the questionnaire applied, where 2 units of competence were analyzed.

As to the results to the answers of the questionnaire about the online instructional design template, it's interpreted that $87 \%$ of the students agree and completely agree that the platform has clear and precise instructions for the activities and the homework. As to the organization of the course, $100 \%$ of the students said that they agree and completely agree that the instructions given by the professor were clear and precise. $100 \%$ of the students agree and completely agree that the resources and activities of the course arouse interest to follow it.

In relation to the resources provided in SAETI, $94 \%$ of the students agree and completely agree that the resources used in SAETI are related to the content of the competence units. Regarding the sequence of the units, $100 \%$ agree and completely agree that it helped to understand the issue. In regard to the activities of the course, $94 \%$ of the students agree and completely agree that they were related to the learning and were consistent with the objectives of the course and / or modules. $94 \%$ of the students agree and completely agree that the course materials helped them to understand the program topics of the learning units. Regarding the requirements, goals and objectives of the subject are clear, $94 \%$ of the students agree and completely agree. $100 \%$ of the students agree and completely agree that the instructions by the instructor were clear. $100 \%$ of the students agree and completely agree that the resources and activities of the course, aroused interest to follow it.

Regarding the emphasis placed on selfassessments, $80 \%$ of students agree and completely agree that it helped them understand the topics, $87 \%$ of students agree and completely agree on the participation in interactive forums to help with a better understanding of the issues.

On the other hand, Ramírez (2012) concludes that it should not be forgotten that the multimedia design of a course requires the development of scripts or instructional script where the content expert explains what he wants to convey to the students. These scripts can be used within the activities of developing digital materials on platforms 
that facilitate student learning, where images, icons and pictures are proposed, by using keywords that guide the search for the design of virtual animations with teacher support.

Another study coincides with that conducted by López and Camacho (2012), at the Universidad Autónoma Indígena de México (UAIS), who affirm that new tools are being adopted in their educational programs and are using various techniques of teacher training to achieve it. These new forms include the elaboration of an instructional design of an online course for the educational program of bachelor's degree in accounting, which was the beginning of this initiative, where favorable results were obtained in terms of student learning, with support from digital platforms.

\subsection{Discussion for the third research question}

Regarding the advantages presented to the teacher of the use of an instructional design in the activities of an online course, the data found in the last research question is shown in table 10, where it is stated that the teacher who taught the course completely agreed that the SAETI platform helped in the design of the course, and the interactive activities included in SAETI made possible to know more about the skills and knowledge acquired by the students.

On the other hand, Benítez (2010), states that the development of instructional design models, fundamental and plan the learning for both the teacher and the student, which supports this type of research within the collegiate groups of public or private universities.
In addition, results showed that participants completely agree with the resources provided by SAETI, because it helped identify skills and competences acquired by the students. Therefore, the summative evaluation of the topics proposed by the platform SAETI allowed acquire the knowledge in an active constructive and selfevaluating process, which helped identify the acquired knowledge by the student.

These findings also coincide with the studies of Wen, Wei and Shing (2012), who observed that students who participated in an online argumentative activity, in which they received guidance to organize their interventions, achieved better learning outcomes than their counterparts in the control group regarding the level of discourse obtained from the comparison of two groups of class, control and experimental. With this type of research, the traditional structure of teaching a class is strengthened, regardless of the subject, and also the technique that is provided to the student, since it can not only occur in person, but also in virtual environments by the teachers.

\section{CONCLUSION}

Given the analysis of the results obtained in the present research, it's concluded that the implementation of an instructional design of an online course, in two competence units, increased the student's academic performance, with the results obtained towards the professors, according to the requirements of the course program of bachelor's in administration. In contradistinction with the results obtained from the control group, that received the course in a traditional way, without an online instructional design. 
Also, taking into account the findings, advantages were found for the student and the teachers in terms of the effectiveness of the application of an instructional design in the activities of an online course, such as clear instructions, greater organization in the activities and a great utility in the resources provided by SAETI for the achievement of the objectives of the two units of competence of the course.

\section{ACKNOWLEDGE}

This publication is supported by PFCE 2019.

\section{REFERENCES}

Chacín, R. (2011). La planificación didáctica y el diseño instruccional en ambientes virtuales. Investigación y Postgrado, Julio-Diciembre, 129-160.

Benitez, M. (2010). El modelo de diseño instruccional Assure aplicado a la educación a distancia. Tlatemoani, Revista Académica de Investigación, no1. Disponible en http://www.eumed.net/rev/tlatemoani/01/pdf/6377_mgbl.pdf

Camacho P. (2012). Aplicación de un Modelo Instruccional Constructivista en Línea y sus Efectos en el Rendimiento Académico. Tesis doctoral

Clerici C., Fernández A. and Monteverde A. (2015). Lectura, escritura y rendimiento académico en ingresantes universitarios.Ciencia, Docencia y Tecnología, XXVI Mayo-Sin mes, 35-70.

Dionne, C., Taasoobshirazi, G., Hendricks, S. and Hickey, D. (2012). Argumentation: A strategy for improving achievement and revealing scientific identities. International Journal of Science Education, 30(6), 837861. http://dx.doi.org/10.1080/09500690701411567

Góngora P. and Martínez L. (2012). Del diseño instruccional al diseño de aprendizaje con aplicación de las tecnologías. Teoría de la Educación. Educación y Cultura en la Sociedad de la Información, Noviembre, 342-360.

Hernández, S., R., Fernández, C., and Baptista, L. (2010). Metodología de la investigación. México: McGraw-Hill.

López C., and Camacho V. (2016). Elaboración del diseño instruccional de un curso en línea para el programa educativo de licenciatura en contaduría Uais. Ra Ximhai, 12(6), 421-435.
Martínez R. (2009). El diseño instruccional en la educación a distancia. Un acercamiento a los Modelos. Apertura, Abril-Sin mes, 104-119.

Ortiz B., and Fernández I. (2016). Diseño instruccional para argumentación científica en línea. Interdisciplinaria, 33 (2), 231-249.

Prensky, M. (2009). Sapiens digital: from digital immigrants and digitalnatives to digital wisdom. Recuperado en enero de 2012 de http://www.wisdompage.com/Prensky01.html

Ramírez S. (2012). Un modelo pedagógico para la Educación Virtual... no hay peor ciego que el que no quiere ver. Acta Académica, (50), 11+. Retrieved from http://0go.galegroup.com.novacat.nova.edu/ps/i.do?id=G ALE\%7CA344948322\&v=2.1\&u=novaseu_main\&it=r\&p= GPS\&sw=w\&asid=2bc3460e5820025b12f3195af83939a8

Rodríguez, L. H. and Arbey E. (2012). Algunas precisiones sobre el diseño instruccional. Revista Virtual Universidad Católica del Norte, Febrero-Mayo.

Sharif A. and Cho S. (2015). Diseñadores instruccionales del siglo XXI: cruzando las brechas perceptuales entre la identidad, práctica, impacto y desarrollo profesional. RUSC. Universities and Knowledge Society Journal, Julio, 72-86.

Valdés E., Méndez A. and Rivas, D. (2015). Propuesta de diseño instruccional para gestores de las políticas públicas de educación ambiental en el ámbito no formal. Revista de Investigación, Enero-Abril, 45-69.

Wen, H., Wei, Ch. and Shing, N. (2012). The effectiveness of using procedural scaffoldings in a paper-plus-Smartphone collaborative learning context. Journal Computers \& Education, $\quad 59(2), \quad 250-259$. http://dx.doi.org/10.1016/j.compedu.2012.01.015.. 